\title{
Epitope specificity appears to be an important determinant of in vivo killing ability of simian immunodeficiency virus (SIV)-specific CD8+ T Cells
}

L Pozzi , A Carville, V Varner, J Sen, D Knipe, A Kaur

From AIDS Vaccine 2012

Boston, MA, USA. 9-12 September 2012

\section{Background}

CD8+ cytotoxic T lymphocytes (CTL) are a critical component of antiviral immunity and play an important role in the control of lentiviral infection.

\section{Methods}

We have developed an in vivo CTL assay to directly measure the killing capacity of MHC-restricted SIV-specific CTL in rhesus macaques (RM). In order to evaluate the in vivo efficacy of different epitope-specific CTL, we compared the in vivo killing capacity of Mamu-A*02restricted Nef YY9 and Gag GY9 CD8+ T lymphocytes in three RM vaccinated with a recombinant HSV prime/ DNA boost SIV vaccine regimen.

\section{Results}

Tetramer frequencies of Mamu-A*02-restricted Nef YY9specific CD8+ T-cells were at least 10-fold higher than Mamu-A*02-restricted Gag GY9-specific CD8+ T-cells in individual animals both pre- and post-challenge. Prior to SIV challenge, both CTL populations showed poor and incomplete killing (22-35\%) of target cells over 18 hours. Seven weeks post-challenge, there was a marked increase in the CTL killing capacity of both Nef YY9 and Gag GY9-specific CTL with 26-38\% killing occurring over the first two hours and up to $100 \%$ killing over 18 hours. Surprisingly, Gag GY9-specific CTL consistently showed equivalent or greater in vivo killing when compared to Nef YY9-specific CTL even though the percentages of IFN- $\gamma$ secreting and degranulating cells upon peptide stimulation were comparable.

Harvard Medical School, Southborough, MA, USA

\section{Conclusion}

These data suggest that epitope specificity rather than tetramer frequency determines the ability of SIV-specific CTL to kill infected cells. Taken together, these data may have important implications for the development of a successful HIV vaccine.

Published: 13 September 2012

doi:10.1186/1742-4690-9-S2-O6

Cite this article as: Pozzi et al.: Epitope specificity appears to be an important determinant of in vivo killing ability of simian

immunodeficiency virus (SIV)-specific CD8+ T Cells. Retrovirology 2012 9(Suppl 2):06.
Submit your next manuscript to BioMed Central and take full advantage of:

- Convenient online submission

- Thorough peer review

- No space constraints or color figure charges

- Immediate publication on acceptance

- Inclusion in PubMed, CAS, Scopus and Google Scholar

- Research which is freely available for redistribution
() Biomed Central

Hanvard Medical School, Southborough, MA, USA

ㄷ 2012 Pozzi et al; licensee BioMed Central Ltd. This is an Open Access article distributed under the terms of the Creative Commons Attribution License (http://creativecommons.org/licenses/by/2.0), which permits unrestricted use, distribution, and reproduction in 